\title{
Case Report \\ Surgical Excision of Orbital Progressive Granular Cell Tumour
}

\author{
Demetrio Germanò, ${ }^{1}$ Hossein Mostafa Elbadawy, ${ }^{2}$ Diego Ponzin, ${ }^{2}$ \\ Daniele Ferro, ${ }^{1}$ and Leonardo Priore ${ }^{1}$ \\ ${ }^{1}$ The Department of Maxillofacial Surgery, Ospedale dell'Angelo, Via Paccagnella 11, 30174 Venice, Italy \\ ${ }^{2}$ The Veneto Eye Bank Foundation, Via Paccagnella 11, 30174 Venice, Italy
}

Correspondence should be addressed to Demetrio Germanò; demetrio_germano@yahoo.com

Received 14 March 2015; Accepted 5 May 2015

Academic Editor: Mordechai Rosner

Copyright (C) 2015 Demetrio Germanò et al. This is an open access article distributed under the Creative Commons Attribution License, which permits unrestricted use, distribution, and reproduction in any medium, provided the original work is properly cited.

Granular cell tumour (GCT) is mostly benign lesion first described by Abrikossoff and named after him. Most cases are reported in the head and neck area, where the tongue is the most common site. Here we review previous cases in the literature for GCT in the orbit and present a new case. A 49-year-old male presented with apparent exophthalmos. Examination of the patient revealed the presence of a mass in the bottom side of the orbit. A substantial progress was noted after two months from the initial examination using computed tomography (CT) scan. An orbital mass was extracted and histological analysis showed signs typical for GCT. Immunohistochemistry was positive for S-100; the biopsy showed no mitotic or necrotic areas. Proptosis was resolved after surgery and a six-year follow-up CT scan was performed. We conclude that rapid progress of the tumour does not necessarily suggest malignancy.

\section{Introduction}

Granular cell tumour (GCT) is a commonly benign soft tissue lesion of neural origin according to histochemical and ultrastructure studies [1]. It was first described by Abrikossoff [2] as a granular cell myoblastoma. Up to $10 \%$ of granular cell tumours are multiple [3-5]. A slight female predominance exists, with an estimated female-to-male ratio of approximately $3: 2$. Granular cell tumours affect persons of a wide range of ages. Most patients are middle-aged, with a peak incidence in the fourth through the sixth decades of life. It is widely accepted that the GCT can occur virtually in all parts of the body; nevertheless, head and neck areas are the most affected sites by this type of tumours, with more than two-thirds of those cases diagnosed in the tongue [6]. GCT in the orbit is very rare [7-9]; additionally, malignant orbital GCT was scarcely reported [10-12]. Histological specimen examination and the rate of tumour progress can be two indicative parameters for determining the malignancy of a tumour as early as possible to avoid metastases [11]. Slowly developing tumour can be suggestive of classification as a benign like the majority of GCT. Here we describe the excision of an orbital GCT which rapidly progressed within two months from the first diagnosis. We also report the follow-up of the case for 6 years after surgery.

\section{Case Presentation}

A 49-year-old male patient presented with a history of progressive exophthalmos. Initially, he presented with a minor proptosis. Two months later, a significant progress was noted and ophthalmologic examination revealed a subcutaneous mass with partial occlusion of the lids (Figure 1). Vision acuity was $8 / 10$; however, full ophthalmic examination was not performed due to proptosis and diplopia. The first computed tomography (CT) scan revealed the presence of a spherical solid tumour close to the inferior temporal orbit, with $10.40 \mathrm{~mm}$ in length and $7.99 \mathrm{~mm}$ diameter. The mass (Figure 2) was extracted immediately and histological analysis was carried out. Upon surgical excision of the mass from the bottom of the eye globe the differential diagnosis was suggestive of subcutaneous cysts, granuloma, schwannoma, fibrous histiocytoma, or neurofibroma. Histological staining of the specimen showed that the cells had granular cytoplasm with ill-defined borders, typical for 

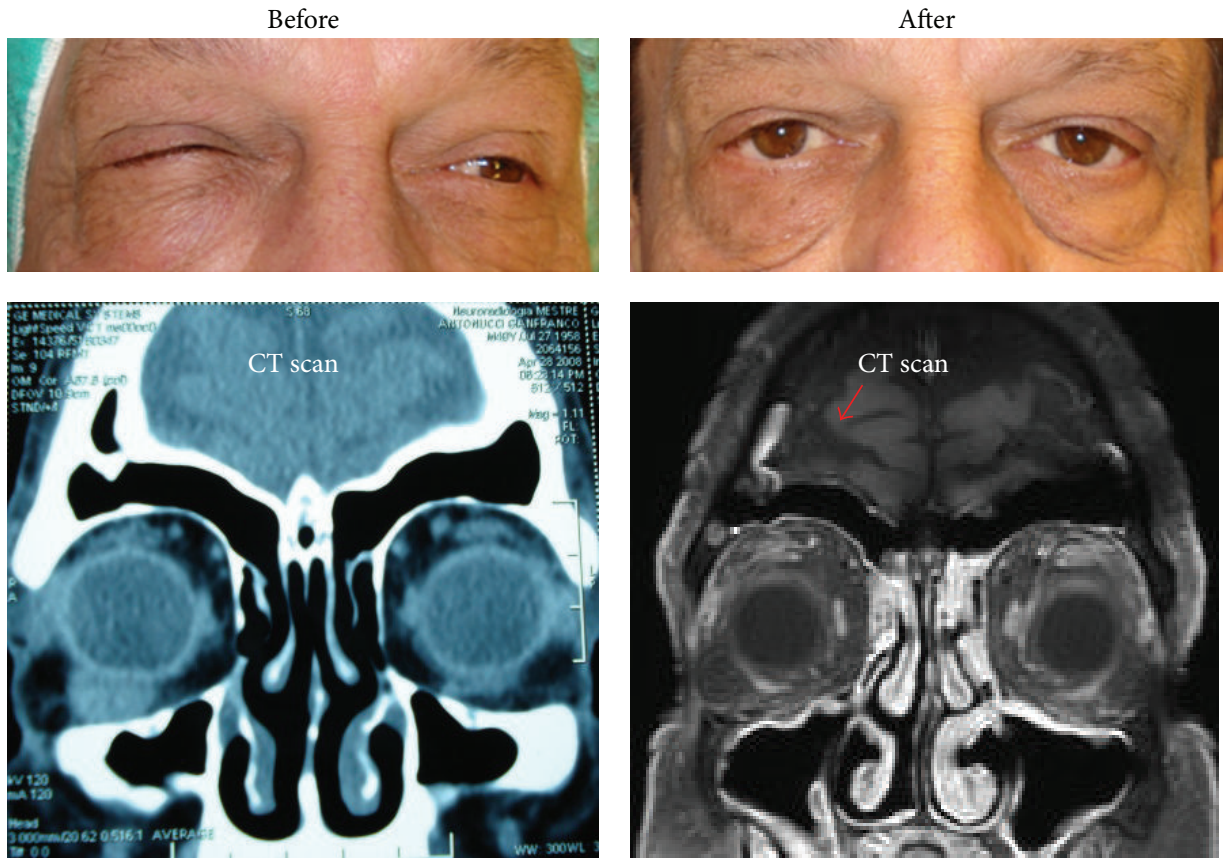

FIGURE 1: GCT before and after surgery. Top panel shows proptosis before (left) and after (right) surgery. Bottom panel shows CT scans to identify the GCT (left), and to confirm the absence of the mass after surgery (right).

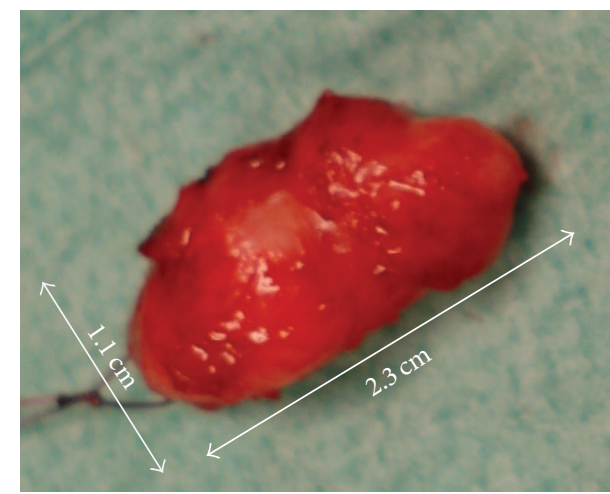

(a)

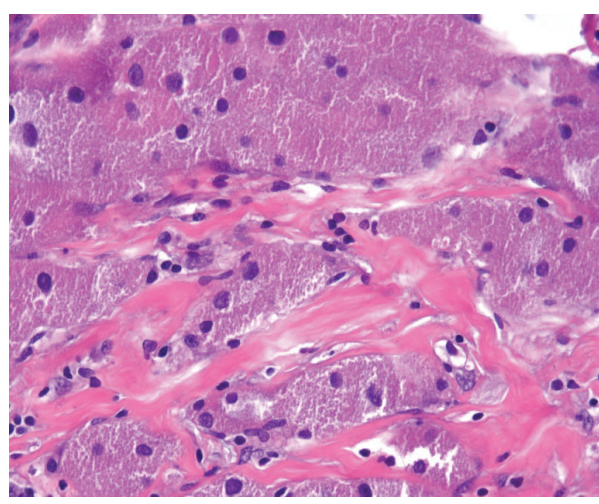

(c)

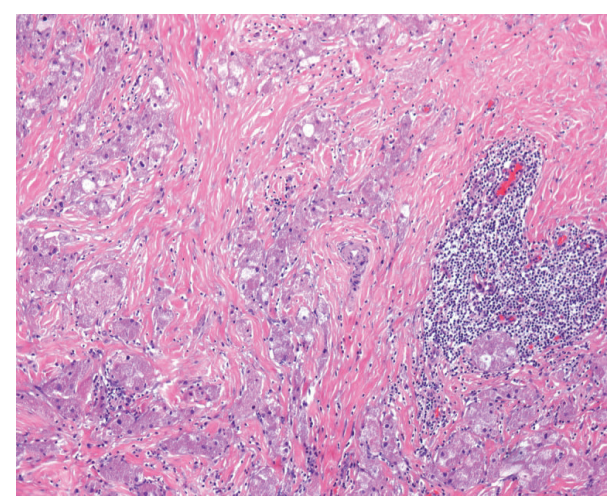

(b)

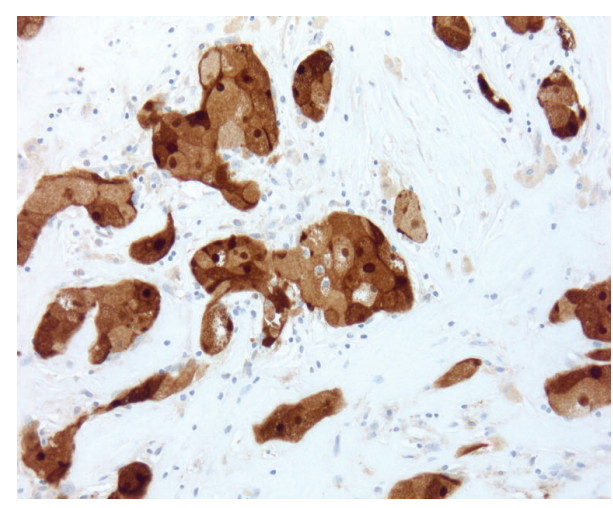

(d)

Figure 2: Histological analysis of the excised mass. Macroscopic examination, showing size and morphology of the mass (a). Histological analysis showed typical GCT histology with granular cytoplasm. Cells were imbedded in a connective tissue bed (b) with batches of high density of nuclei. Cells were large in size with small nuclei and granular cytoplasm (c). Immunohistochemical staining against S-100 protein was positive in the cytoplasm (d). 
TABLE 1

\begin{tabular}{lcccc}
\hline Year & Number of cases & Age & Malignancy & Reference \\
\hline 1975 & 1 & 8 & Benign & {$[13]$} \\
1987 & 1 & 44 & Benign & {$[14]$} \\
1987 & 6 & - & Benign & {$[15]$} \\
1983 & 1 & 65 & Benign & {$[7]$} \\
1983 & 1 & 42 & Benign & {$[16]$} \\
1991 & 4 & - & Benign & {$[8]$} \\
1991 & 4 & $>4$ & Benign & {$[17]$} \\
1994 & 1 & Unknown & Malignant & {$[11]$} \\
1996 & 1 & 30 & Malignant & {$[12]$} \\
1997 & 1 & 43 & Benign & {$[18]$} \\
2000 & 1 & 72 & Malignant & {$[10]$} \\
2004 & 1 & 67 & Benign & {$[19]$} \\
2005 & 1 & 56 & Benign & {$[20]$} \\
2006 & 1 & 49 & Benign & {$[21]$} \\
2007 & 1 & 26 & Benign & {$[22]$} \\
2011 & 1 & 65 & Benign & {$[23]$} \\
2012 & 1 & 53 & Benign & {$[24]$} \\
2012 & 1 & Unknown & Benign & {$[25]$} \\
2013 & 1 & 50 & Benign & {$[26]$} \\
2013 & 1 & 42 & Benign & {$[27]$} \\
\hline
\end{tabular}

GCT. Immunohistochemistry showed S-100 positive staining (Figure 2). The excisional biopsy showed no mitosis or necrotic areas. Proptosis was resolved after surgery and CT scan showed no signs for the presence of GCT (Figure 1). After one year, the vision was restored to $10 / 10$ and there was no sign of diplopia. Regular follow-up for six years following the surgery showed no signs of recurrence of the tumour, which further confirmed the benign nature of the extracted mass.

\section{Discussion}

Abrikossoff's tumour is a rare tumour with commonly benign evolution. CT scan is essential for the correct localization of the mass and early diagnosis is very important to preserve the eye globe. The aim of this report is to describe a case of granular cell tumour in the orbit, to provide a comprehensive summary of previous reports of this case, and to review the malignancy incidence rate of this tumour. The case presented here was suspected to be a malignant tumour due to its fast progress within two months from the first examination; however, histological analysis suggested that it was a benign tumour. This was confirmed by examining the patient regularly for six years. Benign and malignant counterparts are known; the latter are rare, comprising fewer than $2 \%$ of all granular cell tumours. In fact, according to previously reported data (Table 1 ), 3 out of 31 cases were malignant GCT $(9.68 \%)$ in the past 20 years. Therefore, malignancy cannot be ruled out of the differential diagnosis.

Literature review of previous 31 cases shows no age related incidence of GCT in the orbit. Cases reported in age range from 4 years to 72 years, with most cases being reported in patients with 40 years or more. Three cases of GCT malignancy were reported, and the latest was in the year 2000 (Table 1).

\section{Conflict of Interests}

The authors declare no conflict of interests.

\section{References}

[1] R. A. G. Rejas, M.-S. Campos, A.-R. Cortes, D.-D. S. Pinto, and S.-M. De Sousa, "The neural histogenetic origin of the oral granular cell tumor: an immunohistochemical evidence," Medicina Oral, Patologia Oral y Cirugia Bucal, vol. 16, no. 1, Article ID 16859, pp. 6-10, 2011.

[2] A. Abrikossoff, "Über myome," Virchows Archiv für Pathologische Anatomie und Physiologie und für Klinische Medizin, vol. 260, no. 1, pp. 215-233, 1926.

[3] B. E. Calvo, C. Diego Pérez, J. Sancipriano Hernández et al., "Granular cell tumor. A lingual case report," Anales Otorrinolaringologicos Ibero-Americanos, vol. 28, no. 6, pp. 621-629, 2001.

[4] N. Said-Al-Naief, M. Brandwein, W. Lawson, R. Gordon, and H. Lumerman, "Synchronous lingual granular cell tumor and squamous carcinoma: a case report and review of the literature," Archives of Otolaryngology-Head \& Neck Surgery, vol. 123, no. 5, pp. 543-547, 1997.

[5] J. P. Sapp, Patología Oral y Maxilofacial Contemporánea, 2004.

[6] J. D. Noonan, C. E. Horton, W. L. Old, and T. L. Stokes, "Granular cell myoblastoma of the head and neck: review of the literature and 10 year experience," The American Journal of Surgery, vol. 138, no. 4, pp. 611-614, 1979.

[7] Z. A. Karcioglu, G. L. Hemphill, and B. M. Wool, "Granular cell tumor of the orbit: case report and review of the literature," Ophthalmic Surgery, vol. 14, no. 2, pp. 125-129, 1983.

[8] I. Moseley, "Granular cell tumour of the orbit: radiological findings," Neuroradiology, vol. 33, no. 5, pp. 399-402, 1991.

[9] C. E. Poyraz, H. Kiratli, and F. Söylemezoğlu, "Granular cell tumor of the inferior rectus muscle," Korean Journal of Ophthalmology, vol. 23, no. 1, pp. 43-45, 2009.

[10] S. A. Callejo, J. W. Kronish, S. J. Decker, G. R. Cohen, and R. H. Rosa Jr., "Malignant granular cell tumor metastatic to the orbit," Ophthalmology, vol. 107, no. 3, pp. 550-554, 2000.

[11] L. Jardines, L. Cheung, V. LiVolsi, S. Hendrickson, and J. J. Brooks, "Malignant granular cell tumors: report of a case and review of the literature," Surgery, vol. 116, no. 1, pp. 49-54, 1994.

[12] A. Simsir, B. M. Osborne, and E. Greenebaum, "Malignant granular cell tumor: a case report and review of the recent literature," Human Pathology, vol. 27, no. 8, pp. 853-858, 1996.

[13] G. González-Almaraz, S. de Buen, and V. Tsutsumi, "Granular cell tumor (myoblastoma) of the orbit," The American Journal of Ophthalmology, vol. 79, no. 4, pp. 606-612, 1975.

[14] P. J. Dolman, J. Rootman, and C. L. Dolman, "Infiltrating orbital granular cell tumour: a case report and literature review," British Journal of Ophthalmology, vol. 71, no. 1, pp. 47-53, 1987.

[15] M. J. Jaeger, W. R. Green, N. R. Miller, and G. J. Harris, "Granular cell tumor of the orbit and ocular adnexae," Survey of Ophthalmology, vol. 31, no. 6, pp. 417-423, 1987.

[16] E. M. Singleton and M. B. Nettleship, "Granular cell tumor of the orbit: a case report," Annals of Ophthalmology, vol. 15, no. 9, pp. 881-883, 1983. 
[17] A. A. McNab and S. E. Daniel, "Granular cell tumours of the orbit," Australian and New Zealand Journal of Ophthalmology, vol. 19, no. 1, pp. 21-27, 1991.

[18] M. Hashimoto, K. Ohtsuka, T. Suzuki, and T. Nakagawa, "Orbital granular cell tumor developing in the inferior oblique muscle," The American Journal of Ophthalmology, vol. 124, no. 3 , pp. 404-406, 1997.

[19] B. H. Le, P. J. Boyer, J. E. Lewis, and S. B. Kapadia, "Granular cell tumor: immunohistochemical assessment of inhibin- $\alpha$, protein gene product 9.5, S100 protein, CD68, and Ki-67 proliferative index with clinical correlation," Archives of Pathology \& Laboratory Medicine, vol. 128, no. 7, pp. 771-775, 2004.

[20] M. Ahdoot and I. R. Rodgers, "Granular cell tumor of the orbit: magnetic resonance imaging characteristics," Ophthalmic Plastic \& Reconstructive Surgery, vol. 21, no. 5, pp. 395-397, 2005.

[21] D. I. Golio, S. Prabhu, E. F. Hauck, and B. Esmaeli, "Surgical resection of locally advanced granular cell tumor of the orbit," Journal of Craniofacial Surgery, vol. 17, no. 3, pp. 594-598, 2006.

[22] I. Sterker, A. Hagert-Winkler, T. Gradistanac, and B. Frerich, "Granular cell tumor of the orbit," Ophthalmologe, vol. 104, no. 9, pp. 803-805, 2007.

[23] S. Guerriero, G. Giancipoli, A. Sborgia, M. G. Fiore, R. Rossi, and D. Piscitelli, "Orbital granular cell tumor in a patient with churg strauss syndrome: the importance of biopsy," Orbit, vol. 30, no. 1, pp. 30-33, 2011.

[24] B. F. Fernandes, R. B. Neto, A. N. Odashiro, P. R. Pereira, and M. N. Burnier, "Clinical and histopathological features of orbital granular cell tumor: case report," Arquivos Brasileiros de Oftalmologia, vol. 75, no. 2, pp. 137-139, 2012.

[25] S. F. T. Ribeiro, F. Chahud, and A. A. V. Cruz, "Oculomotor disturbances due to granular cell tumor," Ophthalmic Plastic and Reconstructive Surgery, vol. 28, no. 1, pp. e23-e27, 2012.

[26] H. Salour, M. Tavakoli, S. Karimi, M. R. Kanavi, and M. Faghihi, "Granular cell tumor of the orbit," Journal of Ophthalmic \& Vision Research, vol. 8, no. 4, pp. 376-379, 2013.

[27] M. Emesz, E. M. Arlt, E. M. Krall et al., "Granular cell tumors of the orbit-diagnostics and therapeutic aspects exemplified by a case report," Ophthalmologe, vol. 111, no. 9, pp. 866-870, 2013. 


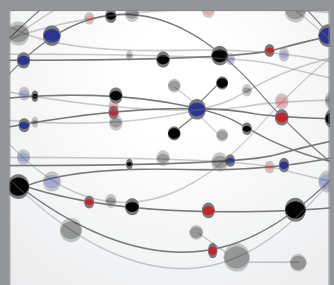

The Scientific World Journal
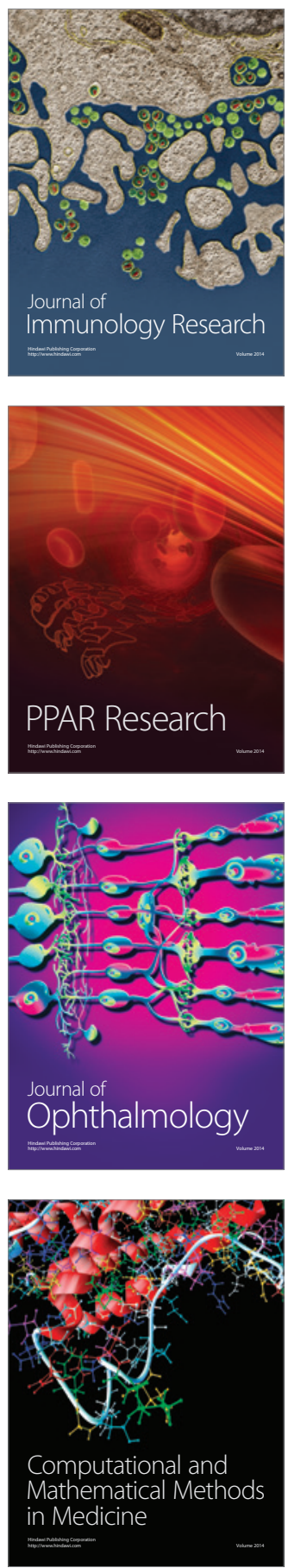

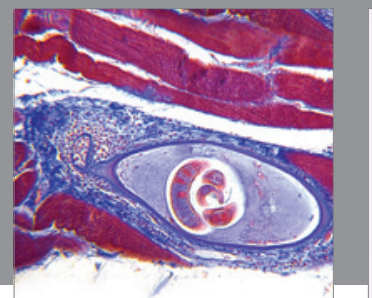

Gastroenterology

Research and Practice
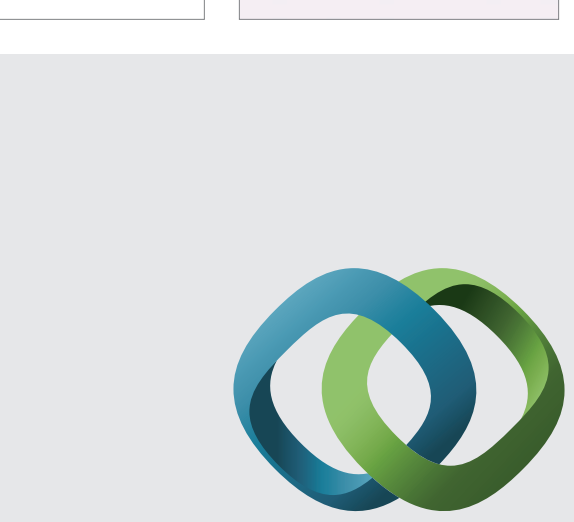

\section{Hindawi}

Submit your manuscripts at

http://www.hindawi.com
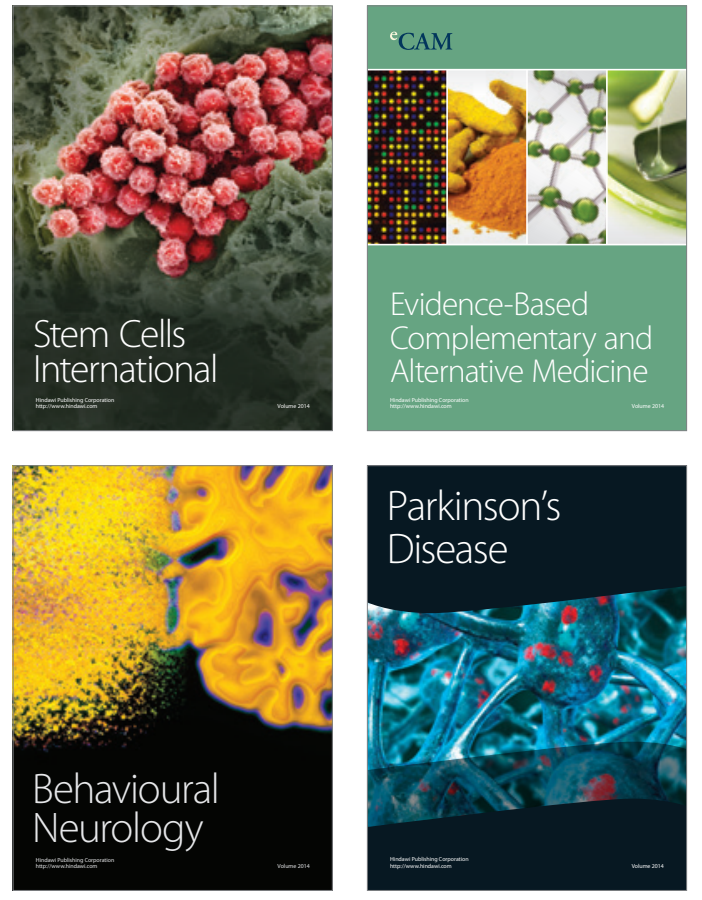
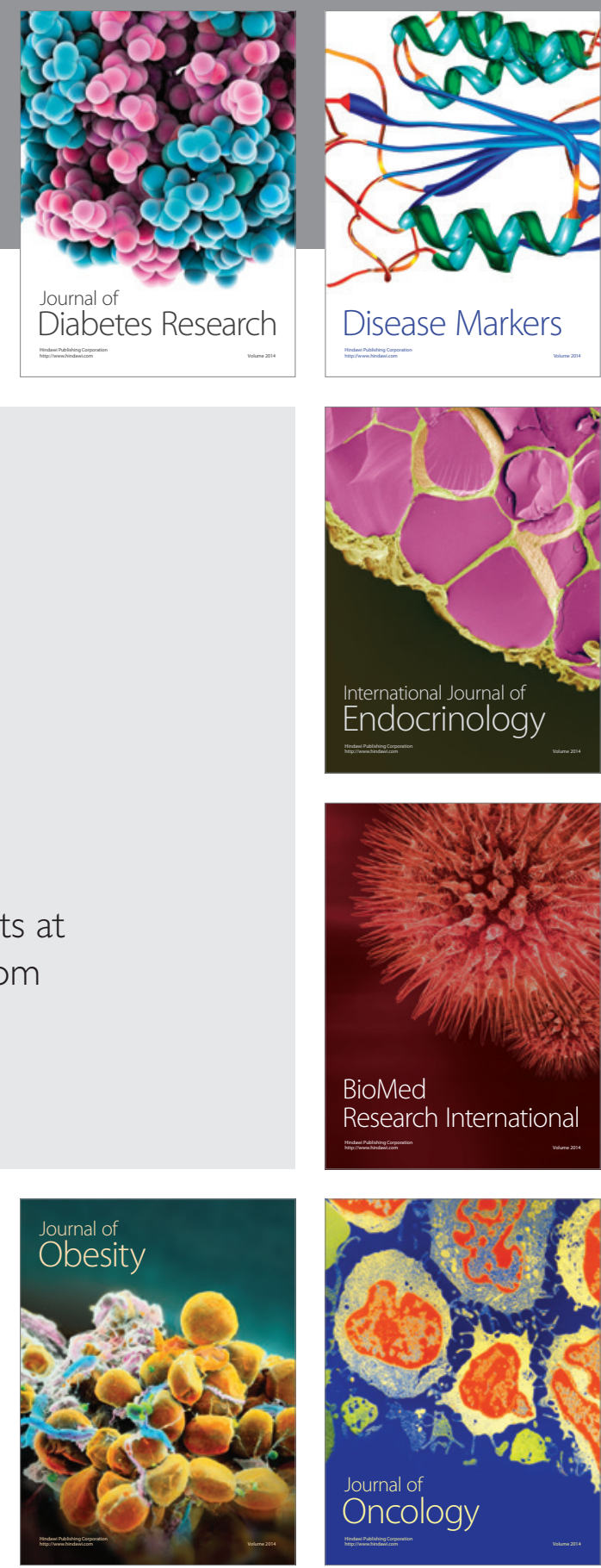

Disease Markers
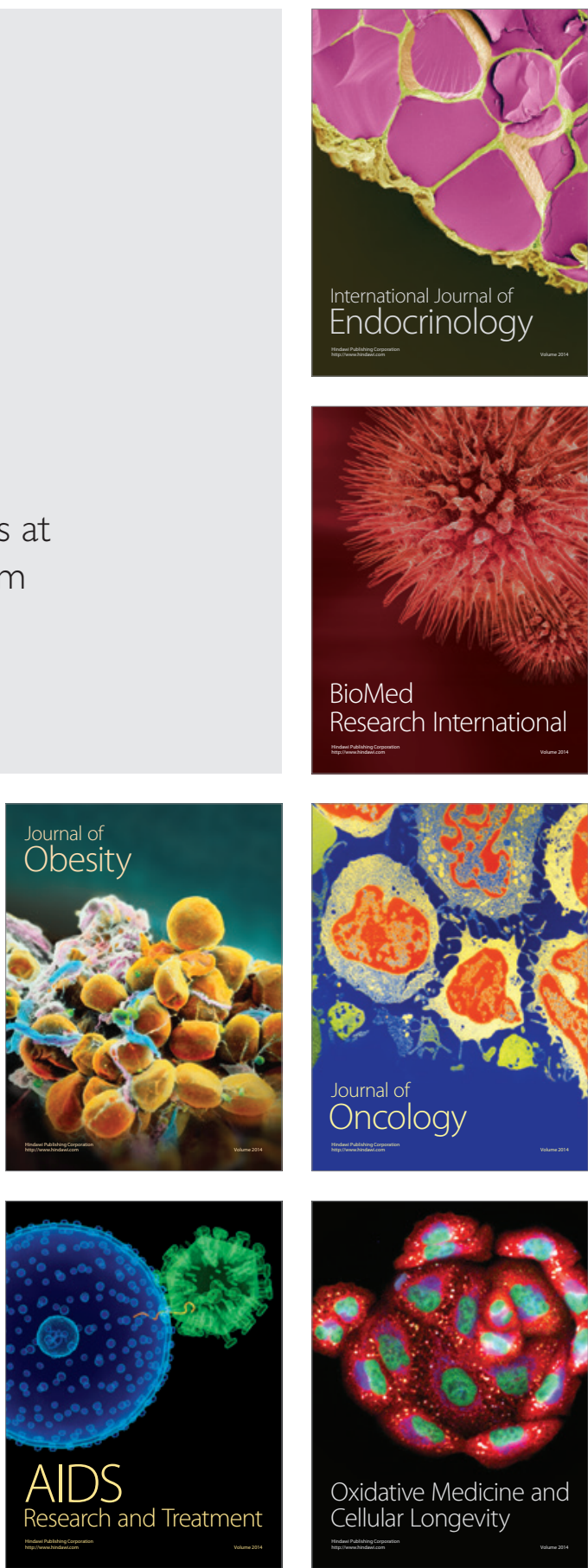